\title{
Ateş Şikayeti İle Acil Servise Getirilen Çocuklarda Ateş Olgularının Değerlendirilmesi*
}

\author{
Evaluation of Fever Incidences for Children Carried to Emergency Services with Fever \\ Complaint
}

\section{Özlem ÖZTÜRK ${ }^{1}$, Aysel TOPAN ${ }^{2}$, Tülay KUZLU AYYILDIZ ${ }^{3}$}

ÖZET Amaç: Bu çalışma, ateş şikâyeti ile acil servise getirilen çocuklarda ateş olgularının değerlendirilmesi amacıyla tanımlayıcı olarak yapılmıştır. Gereç ve Yöntemler: Tanımlayıcı kesitsel tipte araştırmadır. Araştırma, 1 Şubat-1 Mayıs 2014 tarihleri arasında Kadın Doğum ve Çocuk Hastanesi Acil Servisi'nde gerçekleştirilmiştir. Araştırmanın örneklemini belirtilen tarihlerde araştırmaya katılmayı kabul eden 112 çocuk ve ebeveyni oluşturmuştur. Veri toplama aracı olarak 17 sorudan oluşan anket formu kullanılmıştır. Veriler yüz yüze görüşme tekniği ile toplanmıştır. Bulgular: Acil servise getirilen çocukların, \%54.5'inin erkek, \%52.7'sinin 0-3 yaş arasında olduğu; annelerin çocukların ateşi yükseldiğinde, \%76.8'inin doktor önerisi olmadan antipiretik ilaç verdiği, \%54.5'inin ise çocuklarının giysilerini çıkarttığı; acil servise ateş şikayeti ile getirilen çocukların tıbbi tanılarının, \%47.3'ünün solunum yolu enfeksiyonu, \%18.7'sinin tanımlanmamış ateş olduğu belirlenmiştir. Acil serviste \%58.9 ile alın bölgesi, ateş ölçüm bölgelerinde ilk sırada yer alırken, \%52.7'sinin ateş değerlerinin "37.1-38.0" derece olarak belirlenmiştir. Acilde yapılan müdahale ve tedavilerde, sağlik personeli tarafindan çocuğa antipiretik ilaç verilmesi \%74.1 ile ilk sırada yer almıştır. Acilde 1lık uygulama yapma ile acile başvuru sırasında ölçülen ateş değerleri ve acilde ateş ölçmek için kullanılan ateş ölçüm bölgesi ile acile başvuru sırasında ölçülen ateş değerleri karşılaştırılmış olup aralarında istatistiksel olarak anlamlı fark bulunmuştur $(\mathrm{p}<0.05)$. Sonuç: Acile yükssek ateş şikâyeti ile getirilen çocuklarda ateş ölçüm değerlerinin çok yüksek olmadığı görülmesine rağmen, evde anneler ve acil serviste sağlık profesyonelleri tarafindan antipiretik kullanım oranlarının yüksek olduğu görülmüștür.

Anahtar kelimeler: Ateş, çocuk, ebeveynler

\begin{abstract}
Aim: This research is definitively carried for the purpose of evaluation of children brought to the emergency service with fever complaint. Material and Methods: This research is a definitely cross-sectional research carried between $1^{\text {st }}$ February-1 $1^{\text {st }}$ May 2014 in Maternity and Children's Hospital Emergency Service. The universe of research consists of 112 children and their parents who accepted to join the research between these dates. A survey form containing 17 questions has been used, and the data was collected by face-to-face interview. Results: Of all the students, $54.5 \%$ is male, and $52.7 \%$ is between $0-3$ years old. $76.8 \%$ of mothers gives antipyretic medicines without medical advice whereas $54.5 \%$ takes off their clothes. Of all the children carried to the emergency service, $47.3 \%$ has respiratory tract infection, $18.7 \%$ is defined as undefined fever. Of all the fever measurement method, $58.9 \%$ is measured by forehead, $52.7 \%$ is between 37.1 and 38.0 . Antipyretic medication by emergency medical personnel is the first with $74.1 \%$ in the medical intervention and care applied to the children. The warm application in emergency service and the fever measuring part of body were compared with fever value during entering the emergency service, and a statistical difference has been estimated $(p<0.05)$. Conclusion: Although the fever values of children carried to the emergency services were not too high, the antipyretic medicines are widely used by both the mothers in houses and the health professions in emergency services.
\end{abstract}

Keywords: Child, fever, parents

Geliş Tarihi/Received:26.05.2015/Kabul Tarihi/Accepted:21.08.2015

1 Yrd. Doç. Dr.,Karabük Üniversitesi Sağlık Yüksekokulu Hemşirelik Bölümü, Çocuk Sağlığı ve Hastalıkları Hemşireliği Anabilim Dalı, Karabük, İş tel: 03704330202 - 2880, E-mail: zlemzturk@ hotmail.com, Adres: Demir Çelik Kampüsü 78050 Karabük/Türkiye

${ }^{2}$ Yrd. Doç. Dr.,Bülent Ecevit Üniversitesi Sağlık Yüksekokulu Hemşirelik Bölümü, Çocuk Sağlığı ve Hastalıkları Hemşireliği Anabilim Dalı, Zonguldak, İş tel: 03722613362 ,E-mail: ayskose@hotmail.com, Adres: BEÜ Zonguldak Sağllk Yüksekokulu, Kozlu 67600 Zonguldak/Türkiye

3 Yrd. Doç. Dr. Bülent Ecevit Üniversitesi Sağlık Yüksekokulu Hemşirelik Bölümü, Çocuk Sağlığı ve Hastalıkları Hemşireliği Anabilim Dalı, Zonguldak, İş tel: 037226133 62,E-mail: tayyildiz@hotmail.com, Adres: BEÜ Zonguldak Sağlık Yüksekokulu, Kozlu 67600 Zonguldak/Türkiye

**Bu makale 10-13 Haziran 2014 tarihleri arasında İzmir'de düzenlenen 8. Ege Pediatri ve 4. Ege Pediatri Hemşireliği Kongresinde poster bildiri olarak sunulmuş ve üçüncülük ödülü almıştır. 


\section{Giriş}

Ateş, vücut sıcaklığının ölçüldüğg̈ yere göre ortalamadan $1{ }^{\circ} \mathrm{C}$ daha yüksek olmasıdır. Normal ortalama vücut sıcaklığı $37^{\circ} \mathrm{C}$ 'dir. Sicaklık ölçümünün; rektal $38^{\circ} \mathrm{C}$, oral $37.8^{\circ} \mathrm{C}$, aksillar $37.2^{\circ} \mathrm{C}$ 'nin üzerinde oluşu çoğu kaynakta ateş olarak tanımlanmaktadır. ${ }^{1}$

Ateş; infeksiyon, ödem, doku hasarı, aşı gibi nedenlerle vücut 1sısını düzenleyen termoregülatör merkezdeki dengenin bozulması ile ortaya çıkar. Neredeyse tüm çocuklar, çocuklukları boyunca $37.8^{\circ} \mathrm{C}$ ile $40^{\circ} \mathrm{C}$ arasında ateş deneyimlemektedirler. $\mathrm{Bu}$ nedenle çocukluk çağının da en yaygın klinik bulgularından olan ateş, acil servis başvurularının da önemli bir kısmını oluşturur. ${ }^{2,3}$ Yapılan çalışmalarda üç yaşın altındaki çocukların yaklaşık \%19-30'unun ateş nedeniyle acile başvurdukları saptanmıştır. ${ }^{4}$ Bunun yanı sıra ateşli çocukların çok az bir kısmında yaşamı tehdit eden veya sonraki dönemlerde yaşam kalitesini etkileyebilecek infeksiyonlar söz konusudur. $^{2}$

Çocukluk çağının en s1k yakınmalarından biri olan ateş yüksekliği, aileler tarafından yanlış değerlendirilen ve bu nedenle de çoğu zaman uygunsuz tedavi edilen klinik bir durumu tanımlar. ${ }^{5}$ Ateşli çocukların çok az bir kısmında yaşamı tehdit eden ciddi hastalıklar olmasina rağmen aileler çocukları ateşlendiğinde hemen endişelenmekte, gereksiz korku ve panik ile yanlış veya zararlı olabilecek ateş düşürme yöntemlerine başvurabilmektedir. ${ }^{2}$, ${ }^{6}$ Çocuktaki en ufak ısı artışı ateşin hemen düşürülmesi gerektiği fikrini tetiklemekte ve ailede paniğe neden olmaktadır. Öyle ki, zaman zaman normal vücut isılarında bile ateş düşürücü ilaç kullanmak, uyuyan çocuğu uyandirmak, ateşi düşürmek için soğuk su, alkol veya sirke gibi uygulamalar yapmak, antibiyotikleri ateş düşürücü olarak kullanmak, birden fazla antipiretik kullanmak gibi gereksiz hatta zararlı olabilecek uygulamalar yapilmakta ve sonuçta çocukların sağ lı̆̆ etkilenmektedir. Ülkemizde ve yurt dışında yürütülmüş olan çalışmalarda, ateşli çocuğa yaklaşım konusunda gerek ailelerin gerekse sağlık personelinin hatalı yaklaşımının yaygın olduğu bildirilmektedir. ${ }^{2}$

$\mathrm{Bu}$ çalışma, ateş şikâyeti ile acil servise getirilen çocuklarda ateş olgularının değerlendirilmesi amaciyla tanımlayıcı olarak yapılmıştır.

\section{Gereç ve Yöntem}

Tanımlayıcı ve kesitsel tipteki bu çalışma, 1 Şubat-1 Mayıs 2014 tarihleri arasında Zonguldak Kadın Doğum ve Çocuk Hastanesi Acil Servisi'nde gerçekleştirilmiştir. Araştırmanın yürütüldüğü tarihlerde acil servise ateş yakınmasıyla 0-18 yaş grubu 149 çocuk getirilmiştir. Araştırmanın örneklemini belirtilen tarihlerde araştırmaya katılmayı kabul eden 112 çocuk ve ebeveyni oluşturmuştur (Evrenin \%75.2'sine ulaşılmıştır). Araştırmada veri toplama aracı olarak; uzman görüşü alınarak hazırlanmış, açık uçlu ve çoktan seçmeli soruların yer aldığı toplam 17 sorudan oluşan anket formu kullanılmıștır. Anket formunda demografik özelliklerle ilgili 8 soru ve ateşe yönelik 9 soru bulunmaktadır. Araştırmanın yapılabilmesi için, gerekli kurum izinleri alınmıştır. Araştırmaya katılmayı kabul eden ebeveynlere araştırma hakkında bilgi verilerek yazılı ve sözlü onamları alınmıștır. Veriler yüz yüze görüşme tekniği ile toplanarak, her görüşme yaklaşık 10 dakika sürmüştür.

Verilerin istatistiksel değerlendirmesinde SPSS 15.0 programı kullanılmıştır. Sayısal değişkenlerin normal dağılıma uygunlukları Shapiro-Wilk testi ile incelenmiştir. Tanımlayıcı istatistiklerde, sayısal veriler için ortalama \pm standart sapma (minimummaksimum) değerleri; kategorik yapıdaki veriler sayı ve yüzde olarak ifade edilmiştir. Sayısal değişkenler bakımından parametrik test varsayımları sağlandığından iki grubun karşılaştırılmasında Mann-Whitney U testi; üç grubun karşılaştırılmasında KruskalWallis varyans analizi yapılmıştır. Sonuçlar \%95 güven aralığında değerlendirilmiş ve $\mathrm{p}<0.05$ değeri anlamlı kabul edilmiştir. 


\section{Bulgular}

Acil servise getirilen çocukların sosyodemografik özellikleri incelendiğinde; çocukların \%54.5'inin erkek, \%52.7'sinin 0-3 yaş, \%33'ünün 4-8 yaş, \%14.3'ünün 9 yaş ve üzeri olduğu saptanmıştır. Çocukların ebeveynlerinin sosyodemografik özellikleri incelendiğinde; annelerinin \%25.9'unun 27-30 yaş arasında, babaların \%26.8'inin 35-38 yaş arasında olduğu, annelerin \%71.4'ünün ev hanımı, babaların ise \%42.8'inin işçi olduğu saptanmıştır (Tablo 1).

Tablo 1. Ebeveynlerin Sosyodemografik Özellikleri

\begin{tabular}{|c|c|c|}
\hline Özellikler & Sayı $(n=112)$ & $\%$ \\
\hline \multicolumn{3}{|l|}{ Anne yaş } \\
\hline $19-22$ yaş & 7 & 6.3 \\
\hline $23-26$ yaş & 16 & 14.3 \\
\hline $27-30$ yaş & 29 & 25.9 \\
\hline $31-34$ yaş & 22 & 19.6 \\
\hline 35-38 yaş & 24 & 21.4 \\
\hline 39 ve üzeri & 14 & 12.5 \\
\hline \multicolumn{3}{|l|}{ Baba yaş } \\
\hline $23-26$ yaş & 7 & 6.3 \\
\hline $27-30$ yaş & 26 & 23.2 \\
\hline $31-34$ yaş & 22 & 19.6 \\
\hline $35-38$ yaş & 30 & 26.8 \\
\hline 39-42 yaş & 13 & 11.6 \\
\hline 43 ve üzeri & 14 & 12.5 \\
\hline \multicolumn{3}{|l|}{ Anne mesleği } \\
\hline Ev hanımı & 80 & 71.4 \\
\hline İşçi & 8 & 7.1 \\
\hline Memur & 19 & 17.0 \\
\hline Özel sektör & 5 & 4.5 \\
\hline \multicolumn{3}{|l|}{ Baba mesleği } \\
\hline İşçi & 48 & 42.8 \\
\hline Memur & 28 & 25.0 \\
\hline Serbest meslek & 24 & 21.4 \\
\hline Özel sektör & 5 & 4.5 \\
\hline Emekli & 2 & 1.8 \\
\hline İşsiz & 5 & 4.5 \\
\hline
\end{tabular}

Annelerin, ateş ölçme uygulamalarına yönelik dağılımı incelendiğinde; annelerin \%23.2'si evde çocuğun ateşini ölçmediğini ifade ederken, ateş ölçen annelerin \% 70.9'unun

çocuğunun ateşini koltuk altı bölgesinden ölçtüğü belirlenmiştir (Tablo 2). Annelerin çocukların ateşi yükseldiğinde evde yaptıkları girişimler incelendiğinde; annelerin \%76.8'i doktor önerisi olmadan antipiretik ilaç verdiğini, $\% 54.5$ ' $\mathrm{i}$ ise çocuklarının giysilerini çıkarttığını ifade etmiştir (Tablo 3). Çocukların ateş ile birlikte acil servise getirilme nedenleri incelendiğinde; başvuru şikayetlerinde \%68.8 ile "halsizlik" ilk sirada yer alırken, bunu \%66.1 ile "bulant1kusma" ve \%63.4 ile "iştahsızlığın" izlediği görülmüştür (Tablo 4) 
Tablo 2. Annelerin Ateş Ölçme Uygulamalarına Yönelik Dağılımı

\begin{tabular}{lcc}
\hline Özellikler & Sayı & \% \\
\hline Evde ateş ölçme (n=112) & & \\
Evet & 86 & 76.8 \\
Hayır & 26 & 23.2 \\
\hline Ateş ölçme yöntemi (n=86) & & $*$ \\
Koltuk altı & 61 & 70.9 \\
Alın & 10 & 11.7 \\
Ağız & 2 & 2.3 \\
Kulak & 13 & 15.1 \\
\hline Ateş Sınırı (n=86) & & $*$ \\
$36.0-37.0$ derece & 1 & 1.2 \\
$37.1-38.0$ derece & 33 & 38.4 \\
$38.1-39.0$ derece & 40 & 46.5 \\
$39.1-40.0$ derece & 12 & 13.9 \\
\hline
\end{tabular}

*: \% değerleri ateş ölçenlerin sayısı olan 86’ya göre hesaplanmıştır.

Tablo 3. Annelerin Çocukların Ateşi Yükseldiğinde Yaptıkları Girişimlere Göre Dağılımı

\begin{tabular}{lcc}
\hline Yapılan girişimler & Sayı & \% \\
\hline Doğru uygulamalar (n=137)* & 35 & $* *$ \\
Ilık su ile uygulama yapma & 61 & 51.3 \\
Çocuğun giysilerini çıkarma & 41 & 36.5 \\
Çocuğa ılık su ile duş aldırmak & & \\
\hline & & \\
\hline Yanlıs uygulamalar (n=90)* & 86 & 76.8 \\
Doktor önerisi olmadan antipiretik verme & 1 & 0.9 \\
Sirke, alkol, kolonya uygulama durumları & 3 & 2.7 \\
Doktor önerisi olmadan antibiyotik verme & &
\end{tabular}

*: Birden fazla seçenek işaretlenmiştir. **: \% değerleri genel katılımcı sayısı olan 112'ye göre hesaplanmıştır.

Tablo 4. Çocukların Ateş İle Birlikte Acil Servise Başvuru Şikâyetlerine Göre Dağı̆ımı

\begin{tabular}{|c|c|c|}
\hline Özellikler & Sayı & $\%$ \\
\hline Başvuru şikâyeti (n=464)* & & *** \\
\hline Bulant1-Kusma & 74 & 66.1 \\
\hline Halsizlik & 77 & 68.8 \\
\hline İştahsızlık & 71 & 63.4 \\
\hline Huzursuzluk & 61 & 54.5 \\
\hline Öksürük & 46 & 41.1 \\
\hline Burun akıntıs1 & 36 & 32.1 \\
\hline Hırılttli solunum & 28 & 25.0 \\
\hline Kulak ağrısı & 9 & 8.0 \\
\hline S1k nefes alma & 24 & 21.4 \\
\hline İshal & 19 & 17.0 \\
\hline Karın ağrıs1 & 14 & 12.5 \\
\hline Kas ve eklem ağris1 & 5 & 4.5 \\
\hline
\end{tabular}

*: Birden fazla seçenek işaretlenmiştir.**: \% değerleri genel katılımcı sayısı olan 112'e göre hesaplanmıştır.

Acil servise ateş şikayeti ile getirilen çocukların tıbbi tanılarının neler olduğu incelendiğinde; \%25'inin "Üst Solunum Yolu Enfeksiyonu (ÜSYE)", \%22.3'ünün "Alt Solunum Yolu Enfeksiyonu (ASYE)", \%18.7'sinin "tanımlanmamış ateş" ve \%17.9'unun "Gastrointestinal Sistem
(GIS) enfeksiyonları" olduğu

belirlenmiştir. Acil serviste \%58.9 ile alın bölgesi ateş ölçüm bölgelerinde ilk sırada yer alırken, \%52.7'sinin ateş değerleri "37.1-38.0" derece olarak bulunmuştur. Çocukların \%33.9'unun acilde ortalama 1 saat kaldığ 1 , çocukların \%74.1'ine ateş düşürücü ilaç verildiği belirlenmiştir (Tablo 5). 
Tablo 5. Çocukların Acil Serviste Aldıkları Tanı, Ateş Ölçüm Bölgesi, Ateş Ölçüm Değerleri, Yapılan Girişimler ve Acil Serviste Kalış Sürelerine Göre Dağılımı

\begin{tabular}{|c|c|c|}
\hline Özellikler & Sayı & $\%$ \\
\hline \multicolumn{3}{|l|}{ Tanı $(n=112)$} \\
\hline ÜSYE & 28 & 25.0 \\
\hline ASYE & 25 & 22.3 \\
\hline Tanımlanmamış ateş & 21 & 18.7 \\
\hline GİS enfeksiyonları & 20 & 17.9 \\
\hline Otit & 5 & 4.5 \\
\hline Kanserler & 5 & 4.5 \\
\hline Diğer*** & 8 & 7.1 \\
\hline \multicolumn{3}{|l|}{ Acil serviste ateş ölçüm bölgesi $(\mathrm{n}=112)$} \\
\hline Alın & 66 & 58.9 \\
\hline Koltuk altı & 40 & 35.7 \\
\hline Kulak & 6 & 5.4 \\
\hline \multicolumn{3}{|l|}{ Acil servis ateş ölçüm değerleri $(n=112)$} \\
\hline $36.0-37.0$ derece & 2 & 1.8 \\
\hline 37.1-38.0 derece & 59 & 52.7 \\
\hline 38.1-39.0 derece & 46 & 41.1 \\
\hline 39.1-40.0 derece & 5 & 4.4 \\
\hline \multicolumn{3}{|l|}{ Acil serviste kalıș süresi (n=112) } \\
\hline $30 \mathrm{dk}$ & 24 & 21.4 \\
\hline 1 saat & 38 & 33.9 \\
\hline 2 saat & 28 & 25.0 \\
\hline 3 saat -23 saat & 8 & 7.1 \\
\hline 1 gün & 4 & 3.6 \\
\hline 2 gün & 4 & 3.6 \\
\hline 3 gün ve üstü & 6 & 5.4 \\
\hline Acil serviste yapılan müdahale ve tedaviler $(\mathrm{n}=163)^{*}$ & & *** \\
\hline Ateș düșürücü ilaç verilmesi & 83 & 74.1 \\
\hline Antibiyotik tedavisi & 20 & 17.9 \\
\hline Ilık uygulama & 52 & 46.4 \\
\hline Takip & 8 & 7.1 \\
\hline
\end{tabular}

*: Birden fazla seçenek işaretlenmiştir. **: \% değerleri genel katılımcı sayısı olan 112'e göre hesaplanmıştır.

***: Diğer seçeneğinde belirtilen tanıların her biri birbirinden farklıdır.

Ateş şikâyeti ile acil servise getirilen çocukların tıbbi tanıları ile acil servise başvuru sırasında ölçülen ateş değerleri karşılaştırılmış olup, aralarında istatistiksel olarak anlamlı fark bulunmamıştır $(p=0.920)$. Ailelerin evde çocuğun ateşini düşürmek için müdahale yapma durumu ile acile başvuru sırasında ölçülen ateş değerleri karşılaştırılmış olup, aralarında istatistiksel olarak anlamlı fark bulunmamıştır $(p=0.566)$. Çocukların yaşı ile acile başvuru sırasında ölçülen ateş değerleri karşılaştırılmış olup, aralarında istatistiksel olarak anlamlı fark bulunmamıştır $\quad(p=0.292)$. Acilde 1 lik uygulama yapma ile acile başvuru sırasında ölçülen ateş değerleri karşılaştırılmış olup, aralarında istatistiksel olarak anlamlı fark bulunmuştur $(\mathrm{p}=0.024)$. Acilde ateş ölçmek için kullanılan ateş ölçüm bölgesi ile acile başvuru sirasında ölçülen ateş değerleri karşılaştırılmış olup, aralarında istatistiksel olarak anlamlı fark saptanmıştır ( $\mathrm{p}=0.029)$ (Tablo 6). 
Tablo 6. Çocuklara Ait Özelliklere Göre Ateş Durumlarının Değerlendirilmesi

\begin{tabular}{|c|c|c|c|c|}
\hline Özellikler & Sayı & $\begin{array}{c}\text { Ortalama } \pm \\
\text { Std. Sapma }\end{array}$ & $\begin{array}{c}\text { Median } \\
(\text { min-max })\end{array}$ & $\begin{array}{l}\text { Test değerleri } \\
\text { (U-KW; p) }\end{array}$ \\
\hline \multicolumn{5}{|l|}{ Tanı } \\
\hline ÜSYE & 28 & $38.27 \pm 0.69$ & $(37.2-40.0)$ & \multirow{7}{*}{$2.002 ; 0.920^{*}$} \\
\hline ASYE & 25 & $38.07 \pm 0.58$ & $(37.0-39.0)$ & \\
\hline Tanımlanmamış ateş & 21 & $38.25 \pm 0.45$ & $(37.3-39.0)$ & \\
\hline GİS enfeksiyonları & 20 & $38.17 \pm 0.57$ & $(37.3-39.0)$ & \\
\hline Otit & 5 & $37.98 \pm 1.03$ & $(36.6-39.5)$ & \\
\hline Kanserler & 5 & $38.16 \pm 0.39$ & $(37.7-38.7)$ & \\
\hline Diğer*** & 8 & $38.31 \pm 0.68$ & $(37.3-39.1)$ & \\
\hline \multicolumn{5}{|l|}{ Evde müdahale } \\
\hline Evet & 99 & $38.19 \pm 0.62$ & $(36.6-40.0)$ & \multirow{2}{*}{$-0.574 ; 0.566^{* *}$} \\
\hline Hayır & 13 & $38.20 \pm 0.41$ & $(37.5-39.0)$ & \\
\hline \multicolumn{5}{|l|}{ Yaş } \\
\hline $0-3$ yaş & 59 & $38.12 \pm 0.61$ & $(37.0-40.0)$ & \multirow{3}{*}{$2.460 ; 0.292 *$} \\
\hline $4-8$ yaş & 37 & $38.23 \pm 0.64$ & $(36.6-39.5)$ & \\
\hline 9 yaş ve üzeri & 16 & $38.33 \pm 0.44$ & $(37.4-39.0)$ & \\
\hline \multicolumn{5}{|c|}{ Acilde Ilık uygulama yapma } \\
\hline Evet & 52 & $38.33 \pm 0.61$ & $(37.3-40.0)$ & \multirow[t]{2}{*}{$2.275 ; 0.024 * *$} \\
\hline Hayır & 60 & $38.07 \pm 0.58$ & $(36.6-39.0)$ & \\
\hline \multicolumn{5}{|c|}{ Acilde ateş ölçüm bölgesi } \\
\hline Alın & 66 & $38.11 \pm 0.59$ & $(36.6-40.0)$ & \multirow{3}{*}{ 7.112;0.029* } \\
\hline Koltuk altı & 40 & $38.36 \pm 0.59$ & $(37.3-39.5)$ & \\
\hline Kulak & 6 & $37.90 \pm 0.60$ & $(37.3-39.0)$ & \\
\hline Toplam & 112 & $38.19 \pm 0.60$ & $(36.6-40.0)$ & \\
\hline
\end{tabular}

\section{Tartışma}

$\mathrm{Bu}$ çalışma tanımlayıcı bir çalışma olup, ateş şikâyeti ile acil servise getirilen çocuklarda ateş olgularının değerlendirilmesi amacıyla yapılmıştır. Çalışmanın planlama aşamasında ateş şikâyeti ile acil servise getirilen çocukların ebeveynleri ile görüşülmesi tasarlanmış olup, verilerin değerlendirilmesi aşamasında çalışmaya katılan ebeveynlerin tamamının annelerin olduğu görülmüştür. $\mathrm{Bu}$ sonuç, toplumsal aile yapımıza uygun olacak şekilde çalışmadaki çocukların tamamının muayeneye anneleri ile birlikte geldiğini göstermiştir. Çalışmada, ateş şikayeti ile acil servise getirilen çocukların $\% 54.5$ gibi yarıdan fazlasının erkek olduğu belirlenmiştir. Celasin ve arkadaşlarının $(2008)^{7}$ yüksek ateş şikayeti ile çocuk hastanesine getirilen 0-6 yaş grubu çocuklarda yaptıkları çalışmada; çocukların \%62.2'sinin erkek olduğu belirlenmiştir. Agrawal ve arkadaşlarının $(2013)^{8} \quad$ Hindistan'da bir hastanede şikayetlerinden biri ateş olan 14 yaşından küçük çocuklar ile yaptıkları çalışmada ise çocukların \%65.9'unun erkek olduğu bildirilmiştir. Yapılan diğer çalışmalarda da nedeni tam olarak bilinmemekle birlikte ateş şikâyeti ile sağlık kuruluşlarına getirilen erkek çocukların oranlarının kız çocuklarının oranlarına göre daha yüksek olduğu görülmüş ve çalışmamız ile uyumlu bulunmuştur. ${ }^{9,10}$

36 aylıktan küçük çocuklarda ateş yaygin olup, potansiyel olarak ciddi sonuçları bulunmaktadır. ${ }^{11}$ Çalışmada yer alan çocukların \%52.7'sinin 0-3 yaş, \%33'ünün 4-8 yaş, \%14.3'ünün 9 yaş ve üzeri olduğu saptanmıştır. Halıcıoğlu ve arkadaşlarının (2011) ${ }^{9}$ çocuk acil servis ve polikliniğgine ateş nedeni ile başvuran 14 yaş ve altı 500 çocuk ile yaptıkları çalışmada; \%54.8'inin $0-3$ yaş, \%23.4'ünün 4-6 yaş, \%21.6'sının 7-14 yaş olduğu belirlenmiştir. Literatürde yapılan benzer çalışmalarda da ateş şikayeti ile sağlık kuruluşlarına getirilen çocukların önemli bir oranının 0-3 yaş grubu çocuklara ait olduğu görülmüş ve çalışma sonuçlarımızla uyumlu bulunmuştur. ${ }^{7,8,10}$ 
Çalışmaya katılan annelerin \%81.2'sinin 23-38 yaş, \%71.4'ünün ev hanımı olduğu, babaların ise büyük çoğunluğunun bir işte çalıştığ 1 veya emekli, \%4.5 gibi düşük bir oranının işsiz olduğu belirlenmiştir. Celasin ve arkadaşlarının $\quad(2008)^{7} \quad$ yaptıkları çalışmada, annelerin \%63.7'sinin 20-29 yaş grubunda, \%91'inin ev hanımı olduğu bildirilmiştir. Yapılan diğer bir çalışmada da annelerin \%93.2'sinin 21-40 yaşında olduğu belirlenmiştir. ${ }^{9}$ Çalışmamızın sonuçları yapılan bu çalışmalar ile uyumlu bulunmuştur. Çalışmamızda yer alan annelerin büyük çoğunluğunun bir işte çalışmaması ve ev hanımı olması nedeniyle çocukların günlük bakımlarında veya hastalık durumlarında annelerin babalardan daha çok sorumluluk aldıklarını akla getirmektedir. Ayrıca bu yorum, ülkemizde çocuklarda ateş yönetimi ile ilgili yapılan çalışmaların çoğunun annelerle yapılmış olması ile desteklenebilir.

Çalışmaya katılan annelerin \%76.8'i çocuğunu acile getirmeden önce evde ateşini ölçtüğünü belirtirken, evde çocuğunun ateşini ölçen 86 annenin $\% 70.9$ 'u koltuk alt1, \%15.1'i kulak, $\% 11.7$ 'si alın ve \%2.3'ü ise ağız bölgesinden ateşi ölçtüğünü ifade etmiştir. Erdağ ve arkadaşlarının (2010) ${ }^{12}$ çocuk acil polikliniğine ateş şikâyeti ile çocuğunu getiren ebeveynler ile yaptıkları çalışmada; ebeveynlerin \%82'sinin ateş ölçerken koltuk altı bölgesini tercih ettiği belirlenmiştir. Matziou ve arkadaşlarının (2008) ${ }^{13}$ Yunanistan'da bir çocuk hastanesi acil servisine ateş şikayeti ile getirilen çocukların anneleri ile yaptıkları çalışmada; annelerin \%95.4 gibi büyük çoğunluğunun koltuk altı bölgesinden ateşi ölçtüğü bildirilmiştir. Çalışmamızda literatürle uyumlu olarak anneler tarafindan ateş ölçümlerinde "koltuk altı" bölgesinin yüksek bir oranla ilk tercih edilen bölge olduğu görülmüştür. 2,3,5-7,9,14 Ayrıca İtalyan Pediatri Topluluğu'nun "Italian Pediatric Society (IPS)" Çocuklarda Ateş Yönetimi başlıklı yayınladığı (2009) rehbere göre; ebeveynler ya da bakım vericiler için tüm çocukların evde vücut sıcaklığının ölçümünde, dijital termometre kullanılarak koltuk altı bölgesinden ölçüm yapılması önerilmektedir. ${ }^{15}$

Çalışmada annelerin çocuklarının ateşi yükseldiğinde evde yaptıkları girişimler doğru ve yanlış uygulamalar olmak üzere iki şekilde incelenmiştir. Annelerin ateş yönetiminde doğru yaptıkları girişimlerde \%54.5 ile "çocuğun giysilerini çıkarma", \%36.6 ile "çocuğa 1lık su ile duş aldırma", \%31.3 ile "1lık su ile uygulama yapma" yer alırken, yanlış yaptıkları girişimlerde \%76.8 ile "doktor önerisi olmadan antipiretik verme", \%2.7 ile "doktor önerisi olmadan antibiyotik verme", \%0.9 ile "sirke, alkol, kolonya uygulama durumları" yer almıştır. Literatürde yapılan benzer çalışmalarda çocukların ateşini düşürmede soğuk su ile duş aldırmanın ve soğuk uygulama yapmanın anneler tarafından yanlış girişim olarak uygulandığ $1^{5,16,17}$, ayrıca annelerin sirke, alkol, kolonya gibi geleneksel ve hatalı uygulama durumlarının çalışmamızdaki oranlardan çok daha yüksek (sırasıly \%25.4, \%48.8, \%10.5, \%7.7) olduğu görülmüştür. . $^{2,3,7,14}$ Literatürde yapılan diğer çalışmalarda çocuklarda ateşin düşürülmesinde bazı annelerin aspirin kullandıkları ${ }^{7}$ ve doktor önerisi olmadan antibiyotik kullanımının çalışmamızdaki oranlardan çok yüksek (sirasiyla \%16.9, \%14.4, \%26.31) olduğu görülmüştür. ${ }^{2,5,8}$ Çocuklarda çoğu olguda ateş, kendiliğinden geçmesi beklenen viral enfeksiyonlara bağlıdır. $\mathrm{Bu}$ nedenle antibiyotiklerin uygunsuz ve aşırı kullanımı çocuğun iyileşmesine katkıda bulunmayacağ antibiyotiklere karşı bakteriyel direnç gelişimi söz konusudur. ${ }^{18}$ Çalışmamızda annelerin ateş düşürmek için soğuk su ve aspirin kullanmaması, ayrıca sirke, alkol gibi geleneksel uygulamaların ve antibiyotik kullanımının diğer çalışmalara göre çok daha düşük olması olumlu bir sonuç olarak yorumlanabilir. Çalışmamızdan elde edilen bu sonuç, 
çalışma grubunu oluşturan annelerin çocuklarında ateş yönetiminde istendik davranış sergilediklerini akla getirmektedir.

Çocuklarda ateş yönetiminde antipiretik kullanımı yer almasına rağmen, çalışmamızda annelerin çocuklarına doktor önerisi olmadan antipiretik vermesi nedeniyle, bu girişim yanlış uygulamalar başlığ 1 altında incelenmiştir. Çataklı ve arkadaşlarının $\quad(2012)^{6} \quad$ yaptıkları çalışmada; annelerin \%94.7'sinin doktora danışmadan evde ateş düşürücü ilaç kullandığ1 belirlenmiştir. Walsh ve Edwards'ın $(2006)^{19}$ yaptıkları sistematik derleme çalışmasında; ailelerin antipiretiklerin uygun doz ve zamanı konusunda yeterli bilgiye sahip olmadıkları, antipiretikleri bazen normal vücut sicaklığında kullandıkları belirlenmiştir. Zyoud ve arkadaşlarının $(2013)^{16}$ Filistin'de yaptıkları çalışmada, ailelerin \%24.9'unun aynı hasta çocuk için önceki yazılmış reçetelerden, \%4.5'inin hasta çocuğun kardeşlerinden biri için önceki yazılmış reçetelerden ve \%11.9'unun ise reçetesiz olarak antipiretik kullandığ 1 bildirilmiştir. Literatürde yapılan benzer çalışmalarda da annelerde doktor önerisi olmadan antipiretik kullanımının yüksek oranlarda (sırasıyla $\% 78.5, \% 99, \% 97, \% 49.2, \% 45.7$ ) olduğu görülmüş ve bu sonuç çalışmamızla uyumlu bulunmuştur. 3,9,12,13,20 Diğer çalışmalarda olduğu gibi çalışmamızda da antipiretik kullanım oranlarının çok yüksek olmasının nedeni, antipiretiklerin ateşi düşürmekten çok ailelerin kendi stresini ve çocuğun huzursuzluğunu azaltma amaciyla kullanıldığ1 söylenebilir. Hekimlerin, ciddi enfeksiyon belirtilerinin eşlik etmediği hafif ateş durumlarında bile çocuğu rahatlatmak amaciyla ateş düşürücü ilaç önermeleri de ailelerin ateş konusundaki yanlış inanç ve düşüncelerini desteklemektedir. ${ }^{9}$ Buna karşın Sarrell ve arkadaşlarının (2002) $)^{21} \quad$ yaptıkları çalışmada, literatürün önerdiği şekilde 3840 derece ateşte antipiretik kullanmaya başlamanın, doktorlarda $\% 92.3$ ve hemşirelerde $\% 84$ gibi yüksek bir oranda olduğu görülürken ailelerin genelinin ise 37-38 derece ateşte antipiretik kullandığ 1 belirlenmiştir. Dünya Sağlık Örgütü (DSÖ) ise sağlıklı çocuklarda antipiretik ajanların ateş düşürmek amaciyla rutin olarak kullanılmamasını, vücut 1 sisinin $39^{\circ} \mathrm{C}$ ve üzerinde olduğu durumlarda kullanılmasını önermektedir. ${ }^{22}$

Antipiretiklerin dönüşümlü/aralıklı kullanılmasının etkin olduğunu gösteren bilimsel olarak kesinleşmiş veya resmi bir öneri olmamasına rağmen günümüzde farklı antipiretiklerin dönüşümlü/aralıklı kullanımı artmaktadır. Özellikle en sık parasetamol ve ibuprofen kullanımı yaygındır. $^{6,23}$ Ancak Amerikan Pediatri Akademisi "American Academy of Pediatrics (AAP)" ve İngiltere'de yayınlanan ateş yönetimi ile ilgili son rehberler parasetamol ve ibuprofenin kombine ve dönüşümlü kullanımını önermemektedir. ${ }^{24-26}$

Çalışmada, çocukların \%68.8'inin halsizlik, \%66.1'inin bulant1-kusma, \%63.4'ünün iştahsızlık, \%54.5'inin huzursuzluk, \%41.1'inin öksürük, $\% 25$ 'inin hirıltılı solunum, \%17'sinin ishal ve \%12.5'inin karın ağrısı şikayeti olduğu belirlenmiştir. Çocukların \%47.3'ünde solunum yolu enfeksiyonu, \%18.7'sinde tanımlanmamış ateş, \%17.9'unda gastrointestinal sistem enfeksiyonu, \%4.5'inde ise kanser gibi tıbbi tanıların olduğu saptanmıştır. Agrawal ve arkadaşlarının $\quad(2013)^{8} \quad$ yaptıkları çalışmada; çocukların \%72'sinde iştah azalmas1, \%40.9'unda aktivite kayb1, \%36'sinda kusma, \%32.9'sunda irritabilite/ağlama, \%27.4'ünde hızlı solunum, \%27.4'ünde ishalin ateşe eşlik eden, diğer bulgular olduğu belirlenmiştir. Halıcıoğlu ve arkadaşlarının (2011) ${ }^{9}$ yaptıkları çalışmada; ateş nedeni ile hastaneye getirilen çocukların \%75.2'sinde solunum yolu enfeksiyonu, \%11.4'ünde gastroenterit, \%9'unda idrar yolu enfeksiyonu, \%3.6'inda viral döküntü olduğu bildirilmiştir. Öztürk ve arkadaşlarının $(2011)^{10}$ çocuk acil servise 
febril konvülsiyon nedeniyle getirilmiş beş yaş altı çocuklarda yaptıkları çalışmada; çocukların \%83.8'inde solunum yolu enfeksiyonu, \%9.8'inde akut gastroenterit, \%3.1'inde idrar yolu enfeksiyonu, \%1.5'inde aşı reaksiyonu olduğu bildirilmiştir. Çalışmamızda, yapılan diğer çalışmalar ile uyumlu olarak ateşi olan çocukların tıbbi tanılarında solunum yolu ve gastrointestinel sistem enfeksiyonlarının yüksek oranlar ile ilk siralarda yer aldığ 1 görülmüştür. Çalışmada, çocuklarda ateşe eşlik eden şikâyetlerin ise genel olarak solunum yolu ve gastrointestinal sistem hastalıklarına özgü şikâyetler olduğu söylenebilir. Ayrıca çalışmamızda diğer çalışmalardan farklı olarak tıbbi tanılarda tanımlanmamış ateş ve kanser olgularının yer aldığ1 görülmüştür. Literatürde immün sistemin baskılandığı kanser gibi durumlarda ateşin yükselebileceği bildirilmiştir. ${ }^{11}$ Nedeni bilinmeyen ateş ise; enfeksiyondan malignansiye kadar çok geniş bir yelpazeyi kapsamakta ve $38.3{ }^{\circ} \mathrm{C}$ üzerinde en az üç kez ölçülen, en az üç hafta süren ve bir hafta süreyle hastanede yatarak araştırma sonrası tanı konulamamış rektal ateş olarak tanımlanmaktadır. ${ }^{27}$ Çalışmamızda tanılanmamış ateş olgularının yüksek çıkmasının nedeni olarak; acil serviste tanılama işlemlerinin uzun sürmesi ya da acil müdahale yapılması gerekmeyen çocukların acil sağlik personelleri tarafindan polikliniklere yönlendirilmeleri olarak düşünülebilir.

Çalışmada çocukların acil servisteki ateş ölçüm değerleri incelendiğinde; 40 ${ }^{\circ} \mathrm{C}$ 'nin üzerinde ateş olgularının olmadığ $\breve{g}_{\text {, }}$ “39.1-40.0” 'C'de \%4.4 gibi düşük bir oranın yer aldığı belirlenirken, $\% 54.5$ gibi yarıdan fazla bir oranın ' $36.0-38.0$ " ${ }^{\circ} \mathrm{C}$ 'de olduğu görülmüştür. Literatürde yapılan benzer çalışmalarda ise acile ateş nedeni ile getirilen çocuklarda $40{ }^{\circ} \mathrm{C}$ 'nin üzerinde ateş olgularının olduğu ${ }^{28}$, ateş ölçüm değerlerinin bizim çalışmamızdaki değerlerden yüksek (\%85.3'ünde $38^{\circ} \mathrm{C}$ ve yukarısında ateş) olduğu görülmüştür. ${ }^{10}$ Çalışmamızda çocuklarda ateş ölçüm değerlerinin çok yüksek olmaması yapılan bu çalışmalar ile uyumlu bulunmazken, yapılan diğer bir çalışmada ise acil servise ateş şikayeti ile başvuruların önemli bir bölümünün aslında gerekli olmadığ 1 , çocukların ateş yüksekliğinin saptanmadığ 1 ve başvuruların nedeninin ateşin çocuğa zarar verebileceği düşüncesi olduğu belirtilmiş ve çalışmamızla uyumlu bulunmuştur. ${ }^{9} \quad$ Çalışmamızda da çocuklarda ateş ölçüm değerlerinin çok yüksek bulunmaması, ailelerin çocuklarına bir şey olacakları nedeniyle endişe yaşamaları ve bunun sonucunda sağlik kuruluşuna başvurmaları ile açıklanabilir. Yapılan çalışmalarda, çocuklarda ateş nedeniyle fiziksel rahatsızlık yaşamanın 39 ${ }^{\circ} \mathrm{C}$ üstünde oluştuğu bildirilmektedir. ${ }^{24,29}$ Çalışmamızda ise $39{ }^{\circ} \mathrm{C}$ üstünde olgu sayısının çok düşük olmasına rağmen çocuklarda huzursuzluk şikayetlerinin \%54.5 gibi yüksek oranda görüldüğü belirlenmiş ve bu sonuç literatür ile uyumlu bulunmamıştır.

Acilde ölçülen ateş değerleri ortalamaları ile çocukların tanı, yaş ve evde müdahale uygulanma durumları arasında anlamlı farklılık olmadiğ 1 saptanmıştır. Acilde 1lık uygulama yapılan çocukların ateş değerleri ortalamalarının (38.33 \pm 0.61$)$, 1lık uygulama yapılmayan çocukların ateş değerleri ortalamalarına göre $(38.07 \pm 0.58)$ daha yüksek olduğu belirlenmiş olup aralarındaki fark anlamlı bulunmuştur. Ayrica acilde ölçülen ateş değerleri ortalamaları ile ateş ölçüm bölgeleri arasında anlamlı fark olduğu görülmüştür. Çalışmamızda ılık uygulama yapılmasına karar verilen çocukların ateş değerlerinin daha yüksek olması ve ateş ölçüm bölgelerine göre ateş değerleri ortalamalarında farklılık olması beklenilen bir sonuç olarak yorumlanabilir.

Çalışmada çocukların \%80.3 gibi büyük çoğunluğunun acil serviste en fazla 2 saat kaldığ saptanırken, yapilan müdahalelerde \%74.1 ile sağlık personeli tarafindan antipiretik uygulanması ilk sırada yer almıştır. Çalışmamızda ateş şikayeti olan çocukların ateş ölçüm değerlerinin çok yüksek (\%54.5'inde 36.0- 
$38.0{ }^{\circ} \mathrm{C}$ ) ve acilde kalış sürelerinin uzun olmadığ1 görülmesine rağmen sağlık personeli tarafindan antipiretik kullanım oranının yüksek olması, düşük ateş değerlerinde bile gereksiz antipiretik kullanımını akla getirmektedir. Walsh ve arkadaşlarının $\quad(2006)^{30} \quad$ Avustralya'da pediatri hastanesinde çalışan 51 hemşire ile yaptıkları çalışmada hemşirelerin çocuklarda ateş yönetiminde uygulamayı etkileyen olumsuz tutum ve bilgi yetersizliklerinin olduğu belirlenmiştir. Çalışmamızda da çocuklarda ateş ölçüm değerlerinin çok yüksek olmamasına karşın uygulanan gereksiz antipiretik kullanımı acil serviste çalışan sağlık personellerinin ateş yönetiminde olumsuz tutum ve bilgi yetersizliğine sahip olabileceklerini düşündürmektedir.

\section{Sonuç}

Çalışmada, acile yüksek ateş şikâyeti ile getirilen çocuklarda ateş ölçüm değerlerinin çok yüksek olmadığ 1 görülmesine rağmen, evde anneler ve acil serviste sağlık profesyonelleri tarafindan antipiretik kullanım oranlarının yüksek olduğu görülmüştür. Çalışmadan elde edilen sonuçlar doğrultusunda; çocuklarda ateş yönetiminde kullanılabilecek literatürde en son bulunan mevcut kanitlara ulaşılması ve bu kanıtların uygulamalara aktarılması için pediatri ve acil servis hemşirelerinin sürekli eğitimi gereklidir. Ayrıca pediatri hemşirelerinin, primer bakım verici rollerinden biri olan eğitici rollerini kullanarak; çalıştıkları sağlık kurumlarında eğitim toplantıları düzenleyerek ebeveynleri ateş yönetimi konusunda bilgilendirmeleri önerilir.

\section{Yazarların Sorumlulukları}

Araştırmanın tasarımı ÖÖ; verilerin toplanması AT, TKA; verilerin analizi ÖÖ, AT, TKA; makalenin yazımı ÖÖ, AT, TKA tarafından yapılmıştır.

\section{Kaynaklar}

1. Kara B. Çocuklukta ateşle ilgili bilgilerin gözden geçirilmesi [Treating childhood fire related information review]. Sürekli Tıp Eğitim Dergisi [Journal of Continuing Medical Education] 2003;12(1):10-14.

2. Özkan H, Öztürk S. Doğu Anadolu Bölgesinde bir kent merkezinde iki aile sağlığ1 merkezine başvuran annelerin çocukları ateşlendiğinde yaptığ uygulamalar [The applications made by mothers applying to two family health centres in Eastern Anatolia region when their children had fever]. İzmir Dr. Behçet Uz Çocuk Hastanesi Dergisi [Journal of Dr. Behçet Uz Children's Hospital] 2013;3(2):121126.

3. Araz NÇ. Ailelerin ateşli çocuğa yaklaşımı: bilgi, tutum ve uygulamaları [Parents' approach to fever in childhood: Knowledge, attitudes and applications]. Türkiye Çocuk Hast Derg [Turkish Journal of Pediatric Disease] 2013;1:27-32.

4. Luszczak M. Evaluation and management of infants and young children with fewer. American Family Physican 2001;64(7):1219-1226.

5. Saz EU, Koturoğlu G, Duyu M, Ozananar Y, Kurugöl Z, Sever M. Türk ailelerinin ateş yönetimi ile ilgili bilinç düzeyi ve korkuları [Fears of fever and fever management in Turkish families]. Çocuk Enf Derg [J Pediatr Inf] 2009;3:161-164.

6. Çataklı T, Can V, Dallar Y. Annelerin ateş düşürücü kullanma bilgileri yeterli mi? [Is Mothers' Knowledge of Antipyretics Enough?] J Pediatr Inf 2012;6:139-143.

7. Celasin NŞ, Ergin D, Atman Ü. Yüksek ateş şikayeti ile hastaneye yatırılan 0-6 yaş grubu çocukları olan annelerin yüksek ateşe ilişkin bilgi ve tutumlar1 [Attitudes and knowledge concerning high temperature of mothers have 0-6 age group infants who are hospitalized due to high temperature ailments]. Firat Üniversitesi Sağlık Bilimleri Dergisi 
[Firat University Journal of Health Science] 2008;22(6):315-322.

8. Agrawal RP, Bhatio SS, Kaushik A, Sharma CM. Perception of fever and management practices by parents of pediatric patients. Int $\mathbf{J}$ Res Med Sci 2013;1(4):397-400.

9. Halıcıoğlu O, Koç F, Akman SA, Teyin A. Ateşli çocuklarda; annelerin evde ateşe yaklaşımı, bilgileri ve sosyodemografik özellikler ile ilişkisi [In feverish children, mothers' knowledge and home management about fever and its relationship with sociodemographical characteristics]. İzmir Dr. Behçet Uz Çocuk Hastanesi Dergisi [Journal of Dr. Behçet Uz Children's Hospital] 2011;1(1):13-19.

10. Öztürk B, Nalbantoğlu B, Güzel EÇ, Hatipoğlu S, Nalbantoğlu A. Çocuk acil ünitesine febril konvülziyon tanısıyla başvuran beş ay-beş yaş arasındaki çocukların retrospektif olarak incelenmesi [Retrospective analysis of febril convulsion patients aged between 5 months- 5 years old]. Çocuk Dergisi [J Child] 2011;11(3):114-121.

11. Hamilton JL, John SP. Evaluation of fever in infants and young children. Am Fam Physician 2013;87(4):254260.

12. Erdağ GÇ, Akın Y, Girit N, Altuğ H. Ailelerin ateş ve febril konvülsiyon hakkında bilgi düzeyleri [Parent behaviour regarding fever and febrile convulsion]. Zeynep Kamil Tıp Bülteni [Medical Bulletin of Zeynep Kamil] 2010;41(1):1-8.

13. Matziou V, Brokalaki H, Kyritsi $H$, Perdikaris P, Gymnopoulou E, Merkouris A. What greek mothers know about evaluation and treatment of fever in children: An interview study. International Journal of Nursing Studies 2008;45:829-836.

14. Esenay FI, İşler A, Kurugöl Z, Conk Z, Koturoğlu G. Annelerin ateşli çocuğa yaklaşımı ve ateş korkusu [Mothers' approach to feverish child and fever phobia]. Türk Ped Arş [Turk Arch Ped] 2007;42:57-60.

15. Chiappini E, Principi N, Longhi R, Tovo PA, Becherucci P, Bonsignori F, Esposito S, Festini F, Galli L, Lucchesi B, Mugelli A, Martino M. Management of fever in children: summary of the Italion pediatric society guidelines. Clinical Therapeutics 2009;31(8):18261843.

16. Zyoud SH, Al-Jabi SW, Sweileh WM, Nabulsi MM, Tubaila MF, Awang R, Sawalha AF. Beliefs and practices regarding childhood fever among parents: A Cross-sectional study from palestine. BMC Pediatrics 2013;13(66):1-8.

17. Rkain M, Rkain I, Safi M, Kabiri M, Ahid S, Benjelloun BDS. Knowledge and management of fever among moroccan parents. EMHJ 2014;20(6):397-402.

18. Hacımustafaoğlu M. Ateşli çocukta antibiyotik: Ne zaman? [Children in the fiery antibiotics: When?] Güncel Pediatri [The Journal of Current Pediatrics] 2006;3:88-91.

19. Walsh AM, Edwards HE. Management of childhood fever by parents: Literature review. Journal of Advanced Nursing 2006;54(2):217-227.

20. Yiğit R, Esenay F, Şen E, Serinol Z. Annelerin yüksek ateş konusunda bilgi ve uygulamaları [Mothers' information and applications about high fever]. Atatürk Üniversitesi Hemşirelik Yüksekokulu Dergisi [Journal of Atatürk University School of Nursing] 2003;6(3):48-56.

21. Sarrell M, Cohen HA, Kahan E. Physicians', Nurses', and Parents' attitudes to and knowledge about fever in early childhood. Patient Education and Counseling 2002;46:61-65.

22. Eichenwald HF. Fever and Antipyresis. Bull World Health Organ 2003;81(5):372-374.

23. Çiftdoğan DY, Gönülal DA, İkızoğlu HT, Onağ A. Çocuklarda parasetamol sonrasında ibuprofen kullanımının ateş 
kontrolü üzerine etkisi [Efficacy of ibuprofen use after paracetamol on fever control in febrile children]. Ege Pediatri Bülteni [Aegean Paediatric Bulletin] 2008;15(2):69-74.

24. Vitrinel A. Ateşli çocuğa yaklaşım [Management of children with fever]. Türk Aile Hek Derg [Turkish Journal of Family Practice] 2009;13(3):113118.

25. Richardson M, Lakhanpaul M. Assesment and initial management of feverish 1lness in children younger than 5 years: Summary of NICE Guidance. BMJ 2007;334(7604):1163-1164.

26. Mayoral CE, Marino RV, Rosenfeld W, Greensher J. Alternating antipyretics: Is this an Alternative? Pediatrics 2000;105(5):1009-1012.

27. Bozkaya D, Koçak Ü. Çocukluk çağında nedeni bilinmeyen ateş [Fever of unknown origin during childhood]. Türkiye Çocuk Hast Derg [Turkhis J Pediatr Dis] 2009;3(4):57-61.

28. Poirier MP, Collins EP, McGuire E. Fever phobia: A survey of caregivers of children seen in a pediatric emergency department. Clin Pediatr 2010;49(6):530-534.

29. Broome ME, Dokken DL, Broome CD, Woodring B, Stegelman MF. A study of parent/grandparent education for managing a febrile ilness using the calm approach. J Pediatr Health Care 2003;7:176-183.

30. Walsh AM, Edwards HE, Courtney MD, Wilson JE, Monaghan SJ. Paediatric fever management: Continuing education for clinical nurses. Nurse Education Today 2006;26:71-77. 